\title{
Pemberdayaan dan Pengolahan Produk Durian di Desa Juru Mapin, Kecamatan Buer, Kabupaten Sumbawa
}

\section{(Empowerment and Durian Products Processing in Juru Mapin Village, Buer Subdistrict, Sumbawa District)}

\author{
Yadi Hartono $^{1^{*}}$, Ade Mariyam Oklima ${ }^{2}$, Alia Wartiningsih ${ }^{1}$ \\ ${ }^{1}$ Program Studi Agribisnis, Fakultas Pertanian Universitas Samawa, Jln Raya Sering Sumbawa Besar, \\ Kecamatan Unter Iwes, Sumbawa, Nusa Tenggara Barat 61213. \\ 2 Program Studi Agroteknologi, Fakultas Pertanian Universitas Samawa, Jln Raya Sering Sumbawa Besar, \\ Kecamatan Unter Iwes, Sumbawa, Nusa Tenggara Barat 61213. \\ *Penulis Korespondensi: yadihartono82@yahoo.co.id \\ Diterima Juni 2018/Disetujui Januari 2019
}

\begin{abstract}
ABSTRAK
Pengabdian kepada masyarakat (PKM) ini bertujuan untuk meningkatkan pengetahuan sekaligus keterampilan terhadap dua kelompok masyarakat Desa Juru Mapin Kabupaten Sumbawa, yaitu kelompok pembudidaya durian Saling Angkat dan kelompok pengolah buah durian Palopo Durian terutama dalam hal peningkatan produksi, pemasaran, dan manajemen usaha. PKM dilaksanakan mulai Maret-Mei 2018 menggunakan metode pelatihan dan pendampingan. Transfer IPTEK dalam kegiatan pelatihan yang telah digelar, yaitu teknik budi daya dan peremajaan pohon durian, teknik penanganan hama monyet dengan anjing buruan, strategi pembesaran, dan manajemen usaha, serta tata cara pembuatan beberapa jenis kue olahan berbahan baku buah durian. Hasil PKM ini menunjukkan bahwa anggota dari kedua kelompok memahami teknik-teknik budi daya dan peremajaan pohon durian, teknik pemanfaatan anjing buruan dalam penanggulangan hama monyet, teknik pemanfaatan media sosial facebook dalam pemasaran produk secara online dan terampil dalam menghasilkan beberapa jenis kue olahan berbahan baku buah durian.
\end{abstract}

Kata kunci: durian, Jurumapin, pengolahan, Sumbawa

\begin{abstract}
This community partneship program (PKM) is aimed to improve knowledge and skill ofthe two community groups in Jurumapin Village, Sumbawa Regency, namely Saling Angkat farmer groupand Palopo Durian processing group that focuses on develoving the production, marketing and bussines management. This PKM program had been done from March until May 2018 through training and mentoring method. The form of science and technology implementation in the training and mentoring was the technique of cultivating and rejuvenating the durian tree, the technique of using the dog hunter to expose monkey, the technique of marketing and bussines management, and the procedures of producing some cakes from durian. The result of this PKM shows that both of the groups understand the technique of cultivating and rejuvenating the durian tree, the technique of using dog hunter to expulse monkey, the technique of using facebook as social media in online media marketing and they are able to produce some cake from durian.
\end{abstract}

Keywords: durian, Jurumapin, processing, Sumbawa

\section{PENDAHULUAN}

Desa Jurumapin merupakan salah satu desa yang terletak di Kecamatan Buer, Kabupaten Sumbawa dengan luas wilayah $4.667 \mathrm{ha}$, dengan luas lahan pertanian 1.594 ha (BPS Kabupaten Sumbawa 2018). Desa ini juga merupakan desa terluas kedua di Kecamatan Buer. Mata pencarian utama masyarakat Buer adalah di bidang pertanian, diikuti usaha perikanan, peternakan, perdagangan, usaha industri kerajinan rumah tangga, sebagai karyawan, pengangkutan, kehutanan, dan usaha lainnya (BPS Kabupaten Sumbawa 2018). Desa Jurumapin terkenal dengan buah duriannya. Durian Jurumapin dikenal masyarakat lokal sebagai durian yang meriah, setiap pohon memiliki rasa, wangi, dan bentuk yang berbeda. Semua varian menampilkan kualitasnya yang khas. Tahun 2004, Departemen Pertanian yang sekarang diganti namanya menjadi Kementerian Pertanian, mengangkat keunggulan dua varian durian lokal 
Jurumapin menjadi durian unggul nasional. Dua varian itu adalah durian Kepala Gajah dan durian Sedapir. Durian inilah yang membawa nama kabupaten Sumbawa dalam kancah perdurianan nasional bahkan internasional (Kompasiana 2013).

Kelompok pengolah Pelopo Durian merupakan kelompok yang telah memiliki dan menjalankan usaha kecil skala rumah tangga dalam bidang pengolahan buah durian, dan telah didirikan sejak tahun 2012 dengan anggota 20 orang yang terdiri dari ibu-ibu rumah tangga yang ada di Desa Jurumapin, Kecamatan Buer, Kabupaten Sumbawa. Awal mula usaha pengolah buah durian ini didirikan atas dasar keinginan bersama semua anggota kelompok yang sudah terbiasa berkumpul dan berbincang bersama serta susah senang bersama dengan tujuan menambah uang belanja dan membantu meningkatkan pendapatan rumah tangga, rata-rata suami dari anggota kelompok pengolah durian Pelopo Durian adalah petani pembudidaya padi.

Hasil wawancara langsung dilapangan pada tahun 2017, diketahui bahwa usaha pengolahan durian menjadi pelopo durian yang telah berlangsung \pm 2 tahun (2012-2013) dipilih karena bahan baku (durian) yang mudah diperoleh, proses yang mudah dan karena Desa Jurumapin merupakan desa penghasil durian satu-satunya di Kabupaten Sumbawa. Usaha pengolahan durian ini tidak berjalan lancar dan berkelanjutan, hal ini terlihat dari tahun 2014-2017 kelompok pengolah Pelopo Durian mulai tidak aktif dalam memproduksi pelopo durian. Hasil wawancara dengan ketua dan beberapa anggota kelompok, diketahui bahwa terdapat beberapa permasalahan yang menyebabkan usaha tidak aktif di antaranya: 1) Produksi durian di Desa Jurumapin mengalami penurunan dalam beberapa tahun terakhir sehingga harga buah durian (bahan baku) meningkat tajam $\mathrm{Rp}$ 25.000-50.000/buah durian, harga seperti ini menjadi tidak seimbang dengan nilai jual produk pelopo durian; 2) Cakupan daerah pemasaran hanya terbatas di Desa Jurumapin dan dilakukan secara bakulan sehingga produk tidak dikenal luas oleh masyarakat; 3) Rendahnya kesadaran anggota kelompok untuk terus produksi secara berkelanjutan; 4) Daya simpan pelopo durian tidak dapat bertahan lama, sehingga keberadaannya tidak selalu ada dipasaran saat dicari oleh konsumen yang berwisata ke kawasan tangga seribu di Desa Jurumapin; dan 5)
Kemasan produk olahan palopo durian masih sangat standar menggunakan plastik sederhana sehingga tidak dapat mengangkat harga produk olahan yang diproduksi.

Menurunnya produksi durian di desa Jurumapin disebabkan oleh banyaknya durian yang mati dalam beberapa tahun terakhir sehingga perlu dilakukan regenerasi agar keberadaannya tetap ada. Selain itu, masalah lain yang di hadapi dalam budi daya durian adalah tingginya intensitas serangan hama khususnya hama monyet yang menyerang tanaman durian.

Pelaksanaan PKM ini difokuskan pada peningkatan pengetahuan dan keterampilan bagi kelompok Pelopo Durian dan kelompok tani Saling Angkat melalui pelatihan dan pendampingan, sehingga tujuan dari pengabdian kepada masyarakat ini adalah meningkatkan keterampilan dan pengetahuan kelompok pembudidaya durian Saling Angkat dalam mengatasi hama monyet, perawatan, dan peremajaan pohon durian, serta meningkatkan keterampilan dan pengetahuan kelompok pengolah durian Pelopo Durian dalam pemasaran dan mengolah bahan baku durian menjadi produk olahan kreatif.

\section{METODE PELAKSANAAN KEGIATAN}

\section{Tempat dan Waktu}

PKM ini dilaksanakan di Desa Jurumapin, Kecamatan Buer, Kabupaten Sumbawa. Pelaksanaan kegiatan dimulai pada bulan Maret-Mei 2018.

\section{Tahapan dan Metode Pelaksanaan Kegiatan}

Pelaksanaan kegiatan dilakukan melalui tiga tahapan, yaitu tahap persiapan, pelaksanaan, serta monitoring dan evaluasi program.

\section{- Tahap persiapan}

Bentuk kegiatan dalam tahap persiapan adalah pertama, koordinasi dengan pemerintah Desa Jurumapin. Kegiatan ini ditujukan untuk mengkomunikasikan secara umum tentang program PKM mulai dari tujuan program, sasaran, bentuk kegiatan, dan luaran program. Kegiatan koordinasi ini juga sekaligus untuk meminta izin dan dukungan pemerintah desa guna kelancaran selama kegiatan berlangsung. Kedua, persiapan lokasi pelatihan. Kegiatan ini melibatkan kelompok mitra dengan meminta pertimbangan pemerintah desa. Ketiga, per- 
siapan alat dan bahan. Kegiatan ini dilakukan secara bersama-sama dengan kelompok mitra terutama dalam hal pembelian alat dan bahan yang digunakan untuk praktik langsung pembuatan produk (kue) olahan berbahan baku buah durian.

\section{- Tahapan pelaksanaan}

Kegiatan pelatihan dan pendampingan pada kelompok Pelopo Durian dan Tani Saling Angkat dikelompokan menjadi dua, yaitu pelatihan secara teoritis dan praktik teknik budi daya dan pembuatan produk (kue) olahan berbahan baku buah durian. Pelatihan secara teoritis bertujuan memberikan pemahaman teoritis kepada kelompok mitra sesuai dengan kebutuhannya masing-masing. Adapun materi yang disampaikan untuk kelompok tani Saling Angkat selaku kelompok pembudidaya adalah teknik budi daya durian meliputi cara perawatan, pemupukan, dan peremajaan durian, serta cara penanganan musuh atau hama durian terutama monyet. Sedangkan, untuk kelompok Pelopo Durian materi yang disampaikan adalah teknik pemilihan buah durian yang berkualitas, variasi olahan buah durian, teknik pengemasan, pemasaran, dan manajemen usaha. Pada kegiatan ini juga dilakukan evaluasi awal terhadap pemahaman kelompok mitra pada bidangnya masing-masing. Metode pendekatan yang digunakan dalam pelaksanaan evaluasi ini adalah dengan menggunakan kuesioner.

Praktik teknik budi daya bagi kelompok Tani Saling Angkat difokuskan pada teknik peremajaan durian dengan metode stek atau sambung dan pelatihan teknik penanganan hama monyet pada durian dengan memanfaatkan musuh alami (anjing pemburu). Sedangkan, praktik pembuatan kue olahan bagi Kelompok Pelopo Durian difokuskan pada tiga jenis produk kue olahan. Adapun olahan yang dipraktikkan pada kegiatan ini adalah brownies, pancake, dan bolu gulung durian. Kelompok Pelopo Durian diajarkan membuat lapak online dengan memanfaatkan media sosial facebook untuk menjawab permasalahan pemasaran produk, di samping memfasilitasi dengan sejumlah toko-toko kue dan roti yang ada di Kota Sumbawa Besar. Selain itu, untuk menjawab permasalah pembukuan keuangan kelompok Pelopo Durian dilatih tata cara pembukuan keuangan sederhana untuk UKM.

\section{- Monitoring dan evaluasi program}

Monitoring dan evaluasi dalam PKM ini dilakukan pada setiap tahapan kegiatan (on- going) dan evaluasi keseluruhan kegiatan atau evaluasi akhir. Adapun hal-hal yang menjadi fokus dalam pelaksanaan evaluasi diantaranya tingkat partisipasi anggota kelompok mitra pada setiap kegiatan dan peningkatan pengetahuan serta keterampilan anggota kelompok mitra.

\section{HASIL DAN PEMBAHASAN}

\section{Koordinasi Kegiatan dan Respons Pemerintah Desa}

Koordinasi kegiatan dengan pemerintah desa adalah satu dari tiga jenis kegiatan dalam tahap persiapan pelaksanaan PKM ini. Kegiatan ini digelar hari minggu awal bulan Maret 2018. Merujuk pada definisi koordinasi, yaitu sebagai kegiatan yang dilakukan oleh berbagai pihak yang sederajat (equal in rank or order, of the same rank or order, and not subordinate) untuk saling memberi informasi dan mengatur (menyepakati) hal tertentu (Ndraha 2003) maka dalam konteks ini ketua bersama anggota tim PKM turun dan bertemu langsung dengan Pemerintah Desa Jurumapin dan kelompok mitra dalam rangka mengomunikasikan pelaksanaan program PKM mulai dari tujuan program, sasaran kelompok binaan program, bentuk kegiatan, jangka waktu, dan luaran program. Kegiataan koordinasi sekaligus ditujukan untuk meminta izin dan dukungan pemerintah desa dalam rangka menyukseskan pelaksanaan kegiatan PKM tersebut.

Pemerintah Desa Jurumapin mengapresiasi langkah Universitas Samawa (UNSA) yang telah menjadikan Desa Jurumapin sebagai salah satu desa binaan LPPM UNSA dan disampaikan juga ucapan terima kasih khusus untuk dosen yang menjadikan Desa Jurumapin sebagai lokasi program PKM tahun ini. Pemdes bersama-sama masyarakat yang masuk dalam kelompok mitra PKM ini siap berpartisipasi dan mendukung guna kesuksesan pelaksanaan program ini di Desa Jurumapin.

\section{Kegiatan Penyuluhan dan Pelatihan}

Penyuluhan berasal dari kata suluh yang berarti obor atau pelita atau yang memberi terang. Dengan penyuluhan diharapkan terjadi peningkatan pengetahuan, keterampilan, dan sikap. Pengetahuan dikatakan meningkat bila terjadi perubahan dari tidak tahu menjadi tahu dan yang sudah tahu menjadi lebih tahu. Keterampilan dikatakan meningkat bila terjadi perubahan dari yang tidak mampu menjadi 
mampu melakukan suatu pekerjaan yang bermanfaat. Sikap dikatakan meningkat, bila terjadi perubahan dari yang tidak mau menjadi mau memanfaatkan kesempatan-kesempatan yang diciptakan (Ibrahim 2003). Sedangkan, pelatihan merupakan proses perbaikan performace pekerja pada suatu pekerjaan tertentu yang sedang menjadi tanggungjawabnya (Gomez-Mejia 2001).

Kegiatan penyuluhan dan pelatihan pada PKM ini ditujukan untuk meningkatkan pengetahuan sekaligus keterampilan pada anggota kedua kelompok, yaitu kelompok Tani Saling Angkat dan kelompok Pelopo Durian. Kegiatan ini berlangsung selama 3 hari, sejak 24-26 Maret 2018. Kegiatan tersebut dihadiri oleh seluruh anggota kedua kelompok mitra. Adapun materi pelatihan yang diberikan meliputi 1) Teknik perlindungan kebun durian dari hama terutama monyet dengan pemanfaatan anjing buruan; 2) Teknik perawatan dan peremajaan tanaman durian; 3) Strategi pemasaran produk bisnis rumahan; 4) Pembukuan keuangan sederhana untuk UKM; dan 5) Pembuatan produk olahan berbahan dasar buah durian. Materi 1 dan 2 disampaikan pada hari pertama, materi 3 dan 4 disampaikan pada hari kedua, sedangkan materi 5 disampaikan pada hari ketiga.

- Pelatihan perlindungan kebun durian dari hama monyet dengan pemanfaatan anjing buruan

Kegiatan tersebut berlangsung di salah satu lahan/kebun durian milik anggota kelompok
Saling Angkat dengan suasana yang intens dan akrab dapat dilihat pada Gambar 1. Spesifikasi materi-materi yang disampikan meliputi pengenalan ciri-ciri fisik anjing yang dapat dijadikan sebagai penjaga kebun/anjing pemburu dan contoh makanan yang baik diberikan untuk konsumsi anjing buruan. Ciri-ciri anjing yang dapat dijadikan sebagai penjaga kebun/anjing pemburu adalah: a) Memiliki dua pusar pada bagian kepala; b) Memiliki pusar pada bokong (pantat); c) Mudah mengonggong ketika melihat musuh; dan d) Ekor berdiri dan bengkok ke arah yang berlawangan dengan arah daun telinga (dapat dilihat pada Gambar 2). Ciri-ciri fisik yang demikian menurut pengetahuan lokal (local knowledge) memiliki kemampuan berburu sangat baik tanpa banyak harus dilatih. Lebih lanjut narasumber menjelaskan bahwa untuk menjaga anjing tetap baik dalam berburu makanan yang diberikan juga harus tetap dijaga. Salah satu jenis makanan yang baik diberikan guna menjaga anjing buruan tetap hebat dalam berburu adalah daging terutama daging dari hewan hasil buruannya. Anjing buruan juga tidak diperbolehkan untuk diberikan tulang.

\section{- Pelatihan tanaman durian}

Secara umum materi terkait teknik perawatan/peremajaan tanaman durian meliputi cara dan manfaat dilakukan penjarangan, penyulaman dan penyiangan, teknik dan manfaat pemangkasan akar, teknik pembentukan ta-

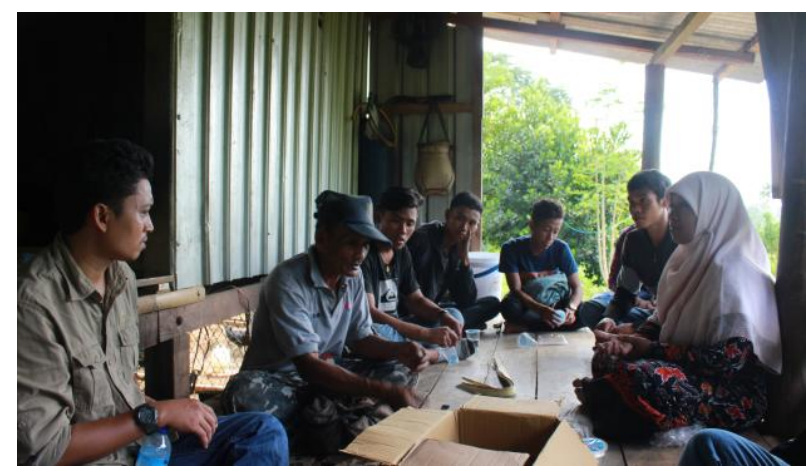

Gambar 1 Suasana pelatihan anjing penjaga kebun durian.
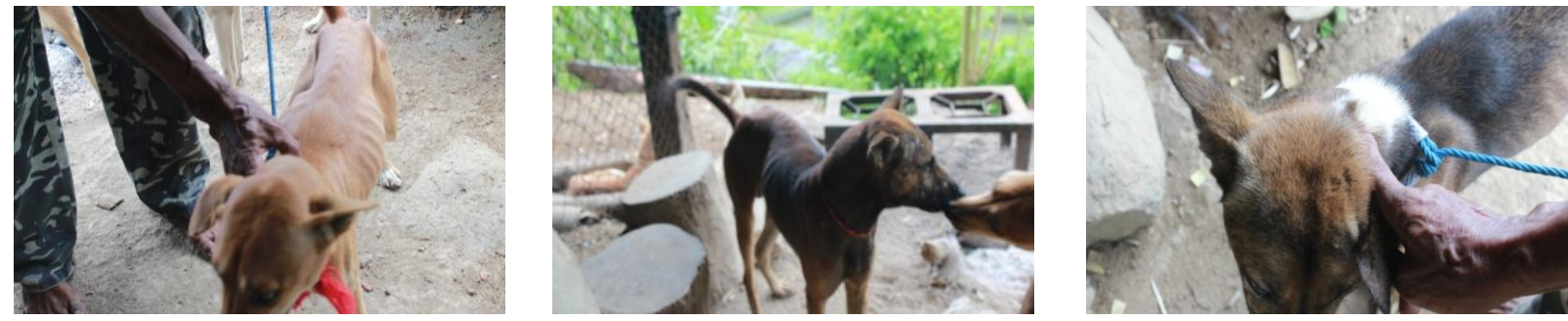

Gambar 2 Jenis/tanda fisik anjing yang digunakan sebagai penjaga kebun/anjing buruan. 
naman durian yang terlanjur tua, jenis, dosis dan teknik pemupukan, teknik pengairan, waktu penyemprotan pestisida, dan pemeliharaan lainnya. Pada materi ini disampaikan langsung oleh anggota tim PKM dan kegiatan langsung dipraktikkan oleh kelompok Tani Saling Angkat.

\section{- Pelatihan startegi pemasaran bagi produk bisnis rumahan}

Strategi pemasaran adalah logika pemasaran di mana unit bisnis berharap untuk menciptakan nilai dan memperoleh keuntungan dari hubungannya dengan konsumen (Kotler \& Amstrong 2008). Sedangkan menurut Kurtz (2008) strategi pemasaran adalah keseluruhan program perusahaan dalam menentukan target pasar dan memuaskan konsumen dengan membangun kombinasi elemen dari marketing mix, yaitu produk, distribusi, promosi, dan harga. Merujuk pada definisi tersebut dan melihat karakteristik produk serta skala usaha dari kelompok mitra Pelopo Durian maka materi yang disampikan mencakup: teknik pemasaran dengan menggunakan teknik konvensional versus teknik digital/online, kenapa harus digital pemasaran online, dan teknik pemanfaatan/pembuatan akun sosial media seperti facebook dalam pemasaran produk online. Hasil pelatihan pembuatan facebook yang dilakukan kelompok mitra dengan nama Agri Mart UNSA dapat dilihat pada Gambar 3.

\section{- Pelatihan pembukuan keuangan sederhana bagi UKM}

Laporan keuangan menurut Standar Akuntansi Keuangan (SAK) adalah bagian dari proses pelaporan keuangan yang lengkap biasanya meliputi neraca, laporan laba rugi, laporan perubahan posisi keuangan yang dapat disajikan dalam berbagai cara seperti: sebagai laporan arus kas, atau laporan arus dana, catatan, dan laporan lain serta materi penjelasan yang merupakan bagian integral dari laporan keuangan. Baridwan (2004) mendefinisikan laporan keuangan secara sederhana, yaitu ringkasan dari suatu proses pencatatan, merupakan suatu ringkasan dari transaksitransaksi keuangan yang terjadi selama tahun buku yang bersangkutan. Pada pelatihan ini, disamping menjelaskan tentang manfaat dari laporan keuangan bagi usaha, mitra juga diajarkan cara penyusunan laporan keuangan sederhana dalam bentuk penyusunan buku kas, suasana kegiatan pelatihan dapat dilihat pada Gambar 4. Kelompok mitra diperkenalkan pada

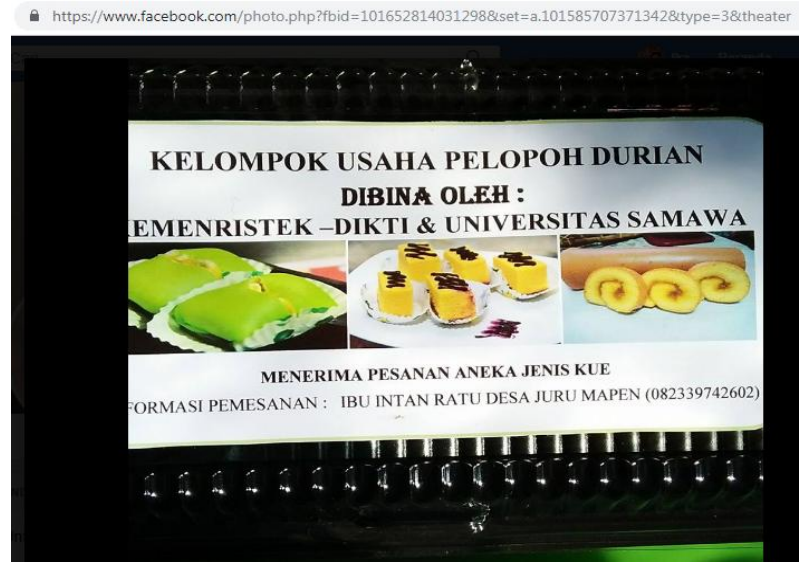

Gambar 3 Akun facebook untuk pemasaran online (Agri mart Unsa).
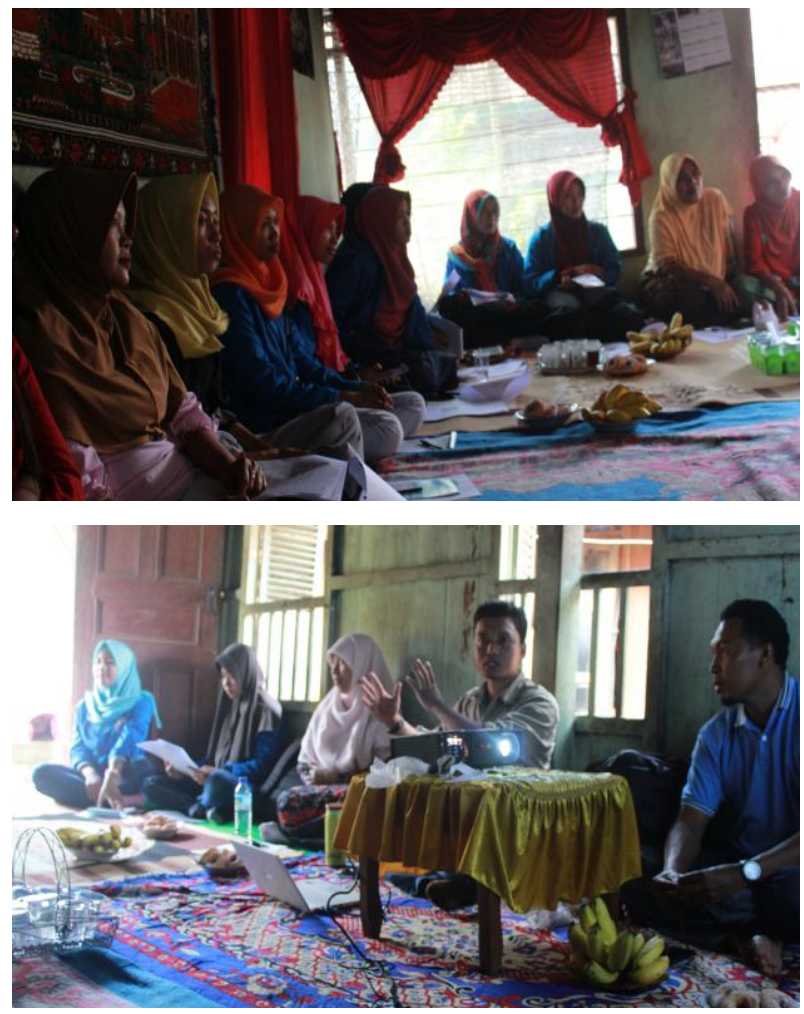

Gambar 4 Suasana kegiatan pelatihan pemasaran dan pembukuan keuangan.

tiga jenis buku kas yang harus dimiliki kelompok, yaitu buku kas pengeluaran, buku kas penjualan, dan buku kas utama. Kemudian diperkenalkan juga pada contoh-contoh dari jenis transaksi yang dicatat dalam masing-masing buku kas.

\section{- Pelatihan pembuatan produk olahan buah durian}

Pelatihan pembuatan produk olahan buah durian yang digelar di hari ketiga difokuskan pada tiga jenis olahan, yaitu pancake, bolu gulung, dan brownies durian. Sebelum masuk pada sesi praktik pembuatan olahan, narasumber menjelaskan beberapa hal mulai dari jenis-jenis 
produk (kue) olahan berbahan baku buah durian, cara pemilihan atau mengenali buah durian yang baik, serta jenis bahan dan alat pendukung yang digunakan. Proses pembuatan produk (kue) olahan berupa brownies, bolu gulung, dan pancake durian dapat dilihat pada Gambar 5.

Hasil kegiatan dari hari pertama hingga hari ketiga menunjukkan hasil yang positif, bahkan seluruh anggota kelompok tani Saling Angkat dan Pelopo Durian merasa sangat berterimakasih atas adanya pelatihan yang dilakukan oleh Tim PKM. Apresiasi yang besar ini ditunjukkan dari hasil wawancara yang dilakukan seusai pelatihan pada hari ketiga mengenai keinginan keberlanjutan kerja sama antara pihak LPPM UNSA dengan kelompok mitra diperoleh hasil, yaitu $100 \%$ anggota kelompok menunjukkan antusiasme ingin agar program dilanjutkkan baik melalui pendampingan maupun pelatihan pada produk-produk olahan baru lainnya.

\section{Monitoring dan Evaluasi}

Menurut Peraturan Pemerintah Nomor 39 Tahun 2006, disebutkan bahwa monitoring merupakan suatu kegiatan mengamati secara seksama suatu keadaan atau kondisi, termasuk juga perilaku atau kegiatan tertentu, dengan tujuan agar semua data masukan atau informasi yang diperoleh dari hasil pengamatan tersebut dapat menjadi landasan dalam mengambil keputusan tindakan selanjutnya yang diperlukan. Menurut Hogwood \& Gunn (1998) memberikan definisi monitoring lebih sederhana, yaitu proses kegiatan pengawasan terhadap implementasi kebijakan yang meliputi keterkaitan antara implementasi dan hasil-hasilnya (outcomes).

Evaluasi menurut Hornby \& Parnwell (dalam Mardikanto 2009) adalah sebagai suatu tindakan pengambilan keputusan untuk menilai suatu objek, keadaan, peristiwa, atau kegiatan tertentu yang sedang diamati. Menurut Soumelis (1981) mengartikan evaluasi sebagai proses pengambilan keputusan melalui kegiatan membandingbandingkan hasil pengamatan terhadap suatu obyek. Monitoring dan evaluasi yang telah dilakukan dalam pelaksanaan PKM ini adalah tingkat partisipasi mitra pada setiap kegiatan, tingkat pengetahuan mitra, dan tingkat keterampilan mitra.

Tingkat partisipasi mitra pada setiap kegiatan evaluasi terhadap tingkat partisipasi ini dilakukan pada setiap rangkaian kegiatan dengan cara memonitoring dan mengevaluasi jumlah kehadiran anggota kelompok mitra (peserta pelatihan). Dari hasil evaluasi didapatkan bahwa partisipasi mitra sangat tinggi dan ini terbukti dari tingkat kehadiran yang direncanakan adalah 25 orang anggota untuk kelompok tani Saling Angkat, dan pada hari kegiatan semua anggota yang diundang hadir, demikian juga yang terjadi pada kelompok Pelopo Durian dari 20 undangan yang disebar pada anggota kelompok, seluruh undangan dapat hadir pada kegiatan selama dua hari yang dilakukan. Di samping itu antusias mitra dalam mengikuti kegiatan juga terbilang sangat tinggi di mana peserta aktif mengikuti seluruh rangkaian kegiatan hingga kegiatan berakhir.

Tingkat pengetahuan mitra dalam melakukan perawatan dan pemeliharaan durian serta pengolahan dan pemasaran hasil olahan durian. Evaluasi ini dilakukan pada tahap awal (pre-test) dan akhir dari kegiatan pelatihan (post-test). Hal ini untuk memastikan tingkat pengetahuan kelompok mitra sebelum dan setelah diadakannya kegiatan PKM. Dalam proses evaluasi menggunakan metode kuesioner dan wawancara. Dari hasil kegiatan bersama kelompok mitra diperoleh hasil yang positif. Hasil pre-test hari pertama bersama kelompok Saling Angkat menunjukkan, dari 11 pertanyaan yang diberikan tentang cara perlindungan kebun durian dari hama monyet, ciri fisik anjing pemburu, dan makan yang dapat diberikan kepada anjing pemburu, cara dan manfaat dilakukan penjarangan, penyulaman dan penyiangan tanaman durian, teknik dan manfaat pemangkasan akar, teknik pembentukan tanaman durian yang

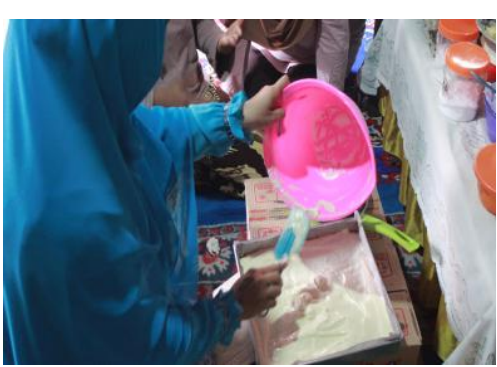

a

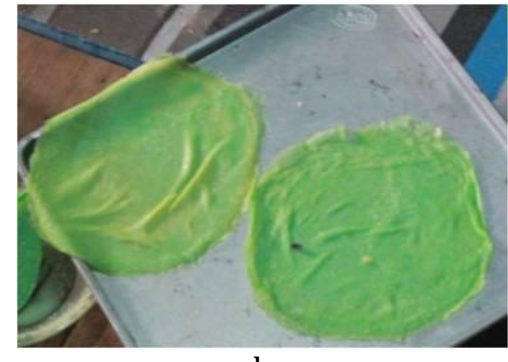

b

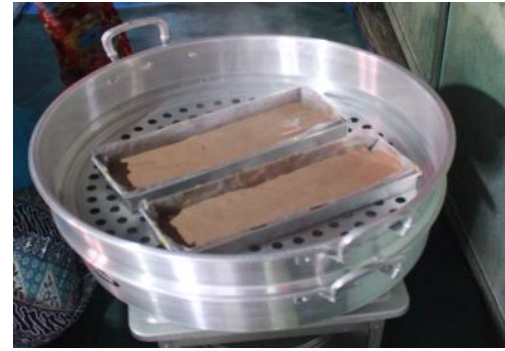

C

Gambar 5 Pembuatan produk (kue) olahan durian, a) bolu durian, b) pancake durian, dan c) brownies durian. 
terlanjur tua, jenis, dosis dan teknik pemupukan, teknik pengairan, waktu penyemprotan pestisida, diperoleh hasil yang rendah, yaitu dari 25 orang anggota kelompok, $40 \%$ atau 10 orang hanya mampu menjawab 1 atau $9 \%$ pertanyaan dengan benar. Sedangkan, bila dibandingkan dengan hasil post-test terjadi peningkatan hasil yang sangat significant, yaitu dari 25 anggota kelompok, $80 \%$ atau 20 orang sudah mampu menjawab 11 atau 100\% pertanyaan dengan benar. Perbandingan hasil antara pre-test dan post-test kelompok tani Saling Angkat dapat dilihat pada Gambar 6. Demikian juga yang terjadi pada kelompok Pelopo Durian dari 11 pertanyaan yang diajukan tentang teknik pemasaran konvensional, tehnik pemasaran digital/online, teknik pemanfaatan/pembuatan akun sosial media seperti facebook dalam pemasaran produk online, laporan keuangan dan manfaat dari laporan keuangan bagi usaha, tata cara penyusunan laporan keuangan sederhana (buku kas) dan produk hasil olahan durian, diperoleh hasil yang masih rendah terutama pada poin pemanfaatan sosial media dalam pemasaran produk, akan tetapi setelah diberikan pelatihan terjadi peningkatan yang cukup significant, di mana hasil analisis menunjukkan pada pre-test dari 20 anggota, 50\% atau 10 anggota hanya mampu menjawab 3 atau $27 \%$ pertanyaan dengan benar dan pada post-test $75 \%$ atau 15 orang anggota mampu menjawab 11 atau $100 \%$ pertanyaan dengan benar. Perbandingan hasil antara pre-test dan post-test kelompok Pelopo Durian dapat dilihat pada Gambar 7.

Tingkat keterampilan mitra PKM dalam melakukan pemeliharaan, perawatan tanaman durian, dan mengolah produk berbahan dasar durian. Evaluasi ini dilakukan terhadap keterampilan mitra dengan metode pengamatan secara langsung pada masing-masing individu peserta pelatihan yang tergabung dalam kelompok mitra. Hasil pengamatan menunjukkan bahwa terjadi peningkatan keterampilan kelompok mitra terhadap budi daya dan pengolahan durian, hal ini terlihat dari aktivitas kelompok mitra pascakegiatan pelatihan, di mana $100 \%$ anggota kelompok mempraktikkan teknik perawatan pohon durian di kebun masingmasing sesuai dengan apa yang diterima selama pelatihan. Demikian juga pada kelompok Pelopo Durian yang telah menguasai cara mengolah brownies, bolu gulung, dan pancake durian bahkan seusai pelatihan ini terjadi beberapa kue olahan berbahan baku durian tersebut, langsung dipasarkan baik secara offline maupun online melalui akun facebook yang telah dibuat pada kegiatan pelatihan dengan omset $\mathrm{Rp} 3.000 .000$.
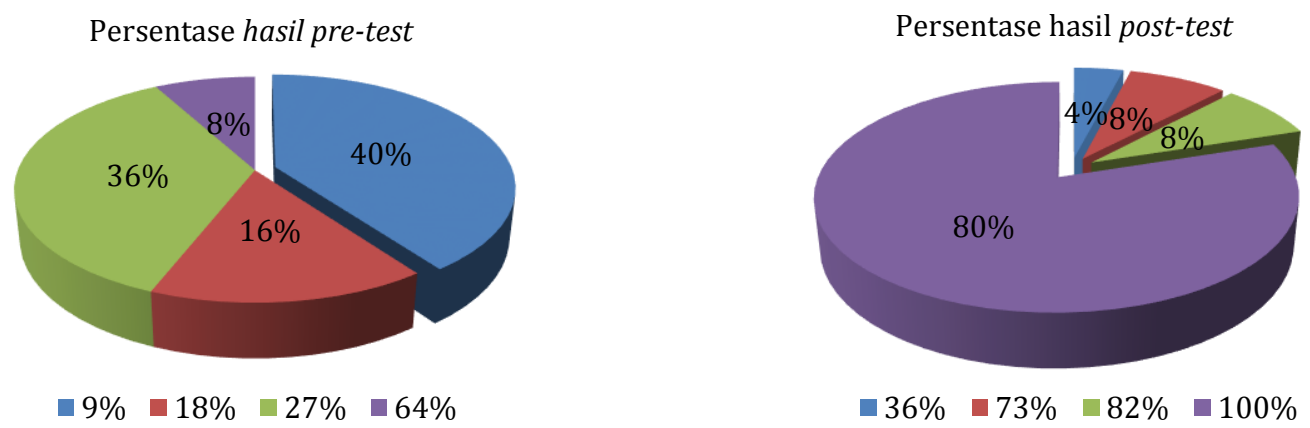

Gambar 6 Perbandingan hasil pre-test dan post-test kegiatan hari pertama bersama kelompok tani Saling Angkat.
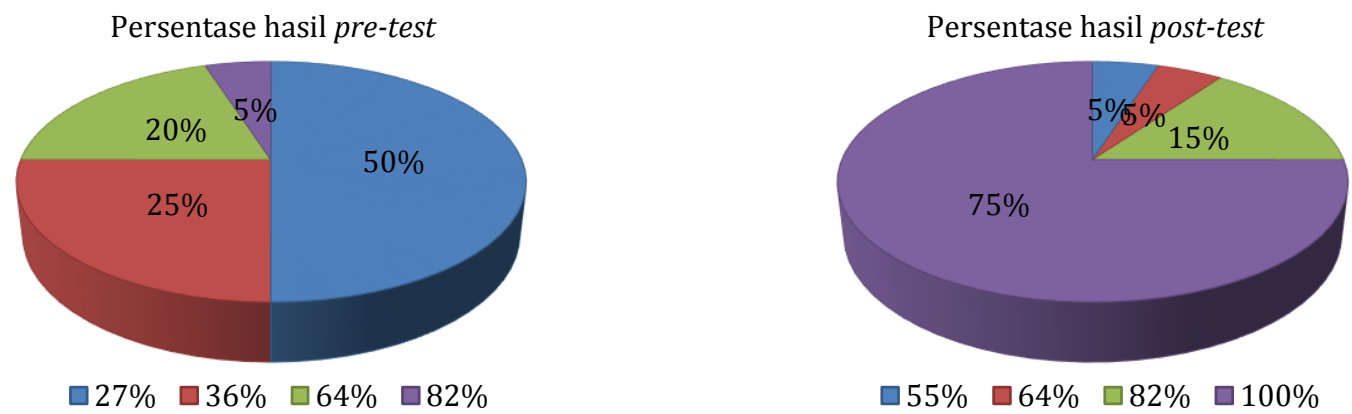

Gambar 7 Perbandingan hasil pre-test dan post-test kegiatan hari pertama bersama kelompok Pelopo Durian. 


\section{SIMPULAN}

Berdasarkan hasil pelaksanaan kegiatan PKM terdapat peningkatan keterampilan dan pengetahuan kelompok pembudidaya durian Saling Angkat dalam mengatasi hama monyet melaui musuh alami anjing pemburu, perawatan, dan peremajaan pohon durian melalui teknik penjarangan, penyulaman dan penyiangan, teknik dan manfaat pemangkasan akar, teknik pembentukan tanaman durian yang terlanjur tua, jenis, dosis dan teknik pemupukan, teknik pengairan. Terjadi peningkatan keterampilan dan pengetahuan kelompok pengolah durian Pelopo Durian dalam pembutan buku kas, pemasaran dengan pemanfaatan sosial media facebook dan pengolahan bahan baku durian menjadi brownies, bolu gulung, dan pancake durian.

\section{DAFTAR PUSTAKA}

Baridwan Z. 2004. Intermediate Accounting. Edisi Kedelapan. Yogyakarta (ID): BPFE.

BPS Kabupaten Sumbawa. 2018. Kecamatan Buer Dalam Angka 2018. Sumbawa (ID): BPS Kabupaten Sumbawa.
Gomez-Mejia LR, Balkin DB, Cardy RL. 2003. Managing Human Resources. International Edition. New Jersey (US): Prentice Hall Inc.

Hogwood BW, Gunn LA. 1998. Policy Analysis For The Real Word. United States (USA): Oxford University Press.

Ibrahim SA. 2003. Eliminating Health Inequalities. American Journal of Public Health. 93(10): 16-18. https://doi.org/10.2105/ AJPH.93.10.1618

Kompasiana. 2013. Penyelamat Biodiversitas Durian. [Internet]. Diakses pada: Januari 2019. Tersedia pada: https://www.kompasiana. com/erwan_saripudin/552fa0926ea8341b03 8b457e/penyelamat-biodiversitas-durian.

Kotler P, Armstrong G. 2008. Prinsip-prinsip Pemasaran. Jilid 1. Jakarta (ID): Erlangga.

Kurtz B. 2008. Contemporary Marketing. New York (US): Sount-West.

Mardikanto T. 2009. Sistem Penyuluhan Pertanian. Surakarta (ID): Sebelas Maret University Press.

Ndraha T. 2003. Budaya Organisasi. Jakarta (ID): Rineka Cipta.

Soumelis CG. 1981. Project Evaluation Methodologies and Techniques. Paris (FR): Unesco. 